\title{
Towards a mechanistic model of amino acid uptake and metabolism by the mammary gland of the lactating dairy cow: A literature review
}

\author{
J. A. Maas', J. France ${ }^{1}$ and B. W. McBride ${ }^{2}$ \\ ${ }^{\prime}$ Centre for Dairy Research, Department of Agriculture, \\ The University of Reading, \\ Earley Gate, PO Box 236, Reading, RG6 6AT, UK \\ 'Department of Animal and Poultry Science, \\ University of Guelph \\ Guelph, ON. NIG 2W1, Canada
}

(Received 30 March 1998; accepted 8 April 1998)

\begin{abstract}
A review is given of information available to produce a dynamic mechanistic model of amino acid uptake and subsequent intracellular metabolism including milk and tissue protein synthesis within the lactating bovine mammary gland. To be a truly mechanistic representation of actual biology the model must address each AA individually, uptake via transporters must be described bidirectionally as has been observed in vitro and in vivo, and the requirements for all mammary origin milk proteins including $\alpha$-lactalbumin and $\beta$-lactoglobulin must be addressed. A conceptual framework for such a model is advanced.
\end{abstract}

KEY WORDS: amino acid, metabolism, model, cattle, mammary gland

\section{INTRODUCTION}

Consider the number of permutations involved in describing a system of synthesis and secretion of 6 milk proteins, produced from 20 amino acids (AAs), concomitant with the synthesis and degradation rates of all components of intracellular protein translation machinery, and fluxes of all metabolites involved. A comprehensive study of such a complicated system would appear to be difficult. However the goal, at some point in the future, is to possess an understanding of this system, in sufficient detail, to predict if bovine milk composition can be ma- 
nipulated, and if so, at which control point(s) in this complex system. Many of the "general principles" of milk synthesis and secretion, which are repeated in numerous revicws, have been developed using data from rodents, or small ruminants such as goats or sheep, and in many cases from very small data sets. Several of these principles have not been corroborated using quantitative data from the lactating dairy cow and therefore must be viewed with some reservation. Thus this review will focus on previous research relating to milk and milk protein synthesis, where ever possible, in a quantitative context as applied to the lactating dairy cow. The method of study employed here is compilation of known information, for use in the development of a dynamic mechanistic model, which forces the investigator to use a structured and quantitative approach. The model produced can then be used to highlight specific areas of knowledge which are important but missing, and thus merit consideration in subsequent experiments.

\section{CURRENT BIOLOGICAL KNOWLEDGE}

The large and diverse body of information, currently available in the literature can be used to structure a mechanistic model of milk protein synthesis, scaled to the size of a lactating dairy cow. Useful information has been derived using both in vitro and in vivo methods.

\section{( $\Lambda$ ) MECHANISMS RESOLVED USING IN VITRO METHODS}

\section{Transport}

Amino acids are transported across biomembranes by a family of $\Lambda \Lambda$ transporters. Thirteen different AA transporters have been characterized, of which three, the A, ASC and L systems appear to be ubiquitous in animal cells (Christensen, 1990). Detailed methods of distinguishing both presence and activity level of the individual AA transporters in tissues have also been developed (Christensen, 1989). Immortalised cells, derived from tissues of hepatic, renal, and blood-brain barrier origin have been the predominant cell types used to characterize AA transport however one attempt has been made to comprehensively characterize the AA transporter population in lactating bovine mammary tissue (Baumrucker, 1985). Development of bovine mammary epithelial cell culture systems, which secrete milk in vitro, and could be used to characterise AA transporter activity, is continuing (Huynh et al., 1991). The specificity of each individual transporter for its substrate $A A$ varies, for example the A system will transport a wider range of AAs than the ASC system. There is considerable overlap, in which specific AAs each transpor- 
ter type conveys across membranes, i.e. several AAs are transported by multiple transporter types. Seven transporter types, including the A and ASC systems, are $\mathrm{Na}+$-dependent, and thus derive their cncrgetic requirements directly from inherent inorganic ion gradients. The L-system transporter is a $\mathrm{Na}^{+}$-independent system, and acts as a counter-transporter operating in a simultaneous bidirectional fashion across a cell membrane, importing one amino acid molecule simultaneously as it exports another, analogous to a revolving door (Christensen, 1990). In cells under experimental conditions in vitro, the L-system transporter usually generates amino acid gradients which are much smaller than those developed by $\mathrm{Na}^{+}$-dependent systems and is very responsive to trans-stimulation, i.e. increasing the intracellular concentration of one amino acid is associated with increased uptake of another.

Seven AA transporters, including A, ASC, and L, have been characterized in bovinc mammary tissue using a mammary tissue slice preparation (Baumrucker, 1985). The results suggest that the L-system transporter is the primary transporter involved in mammary uptake of valine (Val), leucine (Leu), isoleucine (Ile), tyrosine (Tyr), phenylalanine (Phe) and tryptophan (Trp), with methionine (Met) uptake being partitioned between the $\mathrm{L}$ and ASC systems (Baumrucker, 1985). Information from this single set of experiments has been used very widcly in the study of mammary metabolism therefore it would be useful to repeat these experiments, and expand the measurements to include kinetic parameters of transport systems, using established techniques which have applied to other cell types.

Mammary AA transport work (Baumrucker, 1985), along with earlier studies could not resolve mammary uptake of the quantity of sulphur-containing AAs, which appeared inadequate to meet output in milk. An alternate method of $\Lambda \Lambda$ transport was proposed involving the cysteine-containing tripeptide glutathione, by the $\gamma$-glutamyl transpeptidase system, which was initially identified in erythrocytes. The $\gamma$-glutamyl transpeptidase activity level in bovine mammary secretory tissue explants was measured (Baumrucker and Pocius, 1978) but the results were inconclusive and have not been repeated. The authors later showed that rate of AA uptake was variable between mammary tissue taken from different cows, but that uptake across the basal membrane was consistently cxhibited against a concentration gradient, at physiological AA concentrations (Pocius and Baumrucker, 1980).

The presence of ability of cells to alter the rate of AA uptake, known as adaptive regulation, has also been identified in several animal tissues and cells (Guidotti et al., 1978). Reducing the extracellular AA concentration, while holding initial intracellular AA concentration constant, was associated with increased uptake of the A-system transporter substrates alanine ( $\mathrm{Nla}$ ) and serine (Ser), however Leu uptake by L-system did not change in human fibroblast cells grown in culture (Gazzola et al., 1981). However adaptive regulation of the L-system, was demonstrated when increased Leu uptake was associated with increased extracel- 
lular Leu concentration in Chinese hamster ovary cells (Shotwell et al., 1982). Adaptive regulation of the transport systems is attributed, when observed, to altered number of transporters with no change in binding affinity of the transporter for the AA. Kinetic values for Phe transport via the L-system transporter have been reported in cat salivary gland cells (Mann et al., 1980), lymphocytes (Segel et al., 1984, 1988), rat blood-brain barrier membrane (Miller et al., 1985), and virus-transformed blastocyst cells (Gandolfi et al., 1987). The number of transporters per cell was found to range from $1.98 \times 10^{-3}$ to $2.58 \times 10^{-1} \mathrm{mmol}$ of Phe uptake per $\mathrm{ml}$ cell water per hour or about 130 fold from lowest to highest across these tissue types. The affinity of these transporters, usually described as the Michaelis-Menten $\mathrm{K}^{\mathrm{m}}$ value, ranged from $1.20 \times 10^{-2}$ to $2.6 \times 10^{-5} \mathrm{mmol} \mathrm{ml}^{-1}$, or a 462 fold range from lowest to highest, in the same experiments. One set of experiments by Baumrucker et al. (1985) determined only presence or absence of specific AA transporter types in bovine mammary tissue, and not kinetics of $\mathrm{AA}$ transport, therefore large gaps in our knowledge still remain.

A large body of information derived using cell- and tissuc-culture systems, including estimates of kinetic parameters describing AA transport, can be used to structure and parameterize a mechanistic model. These methods will continue to provide valuable kinetic information on AA transport and uptake, which can be utilized effectively but this information must be used with circumspection.

\section{Intracellular metabolism}

Cell- and tissue-culture methods have been used extensively to study mechanisms of mammary metabolism and endocrinology particularly in the area of cancer research with emphasis on human breast cancer (Rosen et al., 1981). Milk production rate, total mammary DNA content, RNA : DNA ratios, and enzymatic activity involved in initiation and maintenance of lactation, were initially charactcrized in the rat (Baldwin and Milligan, 1966). The increase in total DNA content, at parturition suggested that galactopoiesis was associated with a 2 fold increase in lactating cell number, when compared to cell number during late pregnancy. Aspartate aminotransferase activity level, an indicator of rate of AA metabolism, and RNA : DNA ratio increased concomitantly 5 fold and 3.6 fold respectively. When combined these results suggest that cell number increased during the first 5 days of lactation, and that the subsequent increase in milk production was due to increased quantities of synthetic machinery per cell.

Researchers have found it particularly difficult to get mammary cells grown in culture to secrete milk, however much insight has been gained into the specific environmental conditions which cause the cell to initiate and maintain milk synthesis. Expression of milk protein genes in murine (Eisenstein and Rosen, 1988) and bovine (Huynh et al., 1991) cells, grown in culture, are affected by extracellu- 
lar matrix constituents and cell-cell interactions. The ability to develop and maintain polarity, where cells are allowed to orientate in an epithelial tissue layer, with opposite basal and luminal sides also seems necessary (Streuli et al., 1991). Production of $\beta$-casein, in the murine cells, was highest when the cells were grown on collagen gels which were allowed to float in media. Cells plated on collagen gels which were attached to the dish, reduced the rate of casein synthesis, which was further reduced when cells were cultured directly on plastic. The collagen gel appears to facilitate differentiation such that production of a complex basement membrane, similar to the normal extracellular membrane found in mammary tissue, is produced. When plated at high density, on collagen gels, bovine cells rearranged themselves into small organoid-like structures which appeared to have a lumen at the centre of each structure (Huynh et al., 1991). Immunostaining of these cells suggested that synthesis of $\beta$-casein was occurring (Huynh et al., 1991) however the quantity of casein measured in the media, presumably secreted from the cells, was almost undetectable. Explants of rabbit mammary tissue demonstrated the occurrence of intracellular casein hydrolysis, and that the magnitude of hydrolysis was much higher than the minimum necessary to account for post-translational hydrolysis of signal peptide (Razooki Hasan et al., 1982). The authors suggest this as a possible mechanism for controlling the rate of casein synthesis and secretion, by simply recycling all protein produced in excess of some pre-set limit.

Secretion of milk proteins, via exocytosis from the cell can occur immediately after synthesis and packaging into secretory versicles, called constitutive exocytosis, or following variable periods of storage in secretory vesicles, referred to as the regulated exocytosis. Treatment of cells with the $\mathrm{Ca}^{2}{ }^{2}$ ionophore ionomycin, which depletes cytosolic $\mathrm{Ca}^{2}$ concentration, was associated with increased rate of presynthesized protein secretion and was able to stimulate protein secretion after constitutive secretion had terminated (Turner et al., 1992). This suggests that lactating mammary cells have two separate exocytotic pathways, one of which is $\mathrm{Ca}^{21}$-dependent. ${ }^{33}$ S-labelled Met was taken up lincarly by primary-cultured murine mammary cells for the first $5 \mathrm{~h}$ of incubation with no lag period, but secretion of labelled protein from the cells had a lag time of approximately $1 \mathrm{~h}$, consistent with exocytotic secretion (Turner et al., 1992). A system of culturing pre-secretory bovine and ovine mammary gland cells, using serum-free medium and grown on floating type-I rat-tail collagen gels (Winder et al., 1992), expressed $\alpha$-lactalbumin when cortisol, prolactin and insulin were added to the culture medium. Knowledge of the extent of endocrine control of these processes is still incomplete. The process of casein exocytosis, and the association between rate of exocytosis and extent of intracellular protein hydrolysis also require further examination.

Several research groups have studied the endocrine control of lactation and milk synthesis. Addition of prolactin to the culture media caused hypertrophy of murine mammary cells (Foster et al., 1977) and was associated with a 2-4 fold 
increase in the rate of casein mRNA transcription within $1 \mathrm{~h}$ (Guycttc et al., 1979). However this increase in rate of transcription was not sufficient to account for the mass accumulation of casein mRNA observed, suggesting that another mechanism reduced the rate of mRNA degradation, thus casein gene expression could be mediated at several levels including both transcription and translation. These experiments, along with several others involving rodents also established that prolactin secretion was necessary for both initiation and maintenance of lactation. However an experiment, in which prolactin-blocker CB154 was infused into lactating cows, showed that prolactin was not required for maintenance of lactation in the bovine (Akers et al., 1981). While inferences from one species to another are made routinely, consideration of the variation in milk composition described previously (Jenness, 1974) suggests that the possibility of substantial differences in mammary metabolism and function, between species, must also be acknowledged.

\section{(B) MECHANISMS RESOLVED USING IN VIVO METHODS}

\section{Blood flow}

Measurement of AA uptake and metabolism by the lactating mammary gland has relied heavily on arteriovenous difference methodology, often referred to as the Fick principle. The product of total blood flow through the mammary gland, multiplied by the difference in arterial and venous AA concentration gives an estimate of net AA uptake (Guyton, 1974). The Fick method is appropriate to estimate mammary uptake of AA if:

1) both arterial and venous blood samples are representative of blood entering and leaving the tissue;

2) the rate of AA metabolism in the mammary gland is constant;

3) arterial and venous AA concentration is constant;

4) blood flow is constant (Linzell, 1974).

The Fick method is useful in calculating mammary blood flow, or net uptake of a metabolite, however it is not a functional mechanistic definition of metabolite uptake by a tissue (Cant and McBride, 1995a). Thus it is incorrect to assume that mammary uptake can be affected directly by altering either blood flow or arterial metabolite concentration.

The bovine mammary gland is supplied by two arteries, the pudendal artery provides approximately $90 \%$, and the perineal artery provides approximately $10 \%$ of the total supply (Turner, 1952). Mammary venous drainage occurs by three veins in the cow, the subcutaneous abdominal vein, otherwise known as the milk vein, the pudendal vein which passes up through the abdomen to the inguinal canal and joins the vena cava, and the perineal vein, which runs parallel to the perineal 
artery, and drains into the vena cava, near the tail head. The relative proportion of mammary drainage exiting via each vein depends on several factors such as competence of the valves in the subcutancous mammary vein which tends to decline with increasing animal age, and the posture of the animal (Linzell, 1974).

Acquiring a representative arterial blood sample is relatively simple because arterial blood arrives at peripheral tissues directly from the heart, therefore its composition is not altered by tissue metabolism. Thus arterial blood can be sampled from any artery in the animal. Acquiring a representative sample of all the venous blood draining the mammary gland however, is more difficult, particularly in the cow. Mammary venous blood is usually sampled from the subcutaneous abdominal vein, because of its easy access. In mature animals, the valves of the subcutancous abdominal vein can become incompetent (Linzell, 1974), and allow blood of abdominal origin to flow in the reverse direction, caudally, and enter the milk vein, altering its composition. Linzell reduced the possibility of reverse flow in the subcutaneous abdominal veins of goats, by applying gentle hand pressure to the rear of the goats mammary gland, thereby occluding the pudendal vein. This forced all mammary venous drainage to exit via the milk vein, thus insuring that samples taken from the milk vein were representative of mammary venous blood. This procedure also reduced the error in blood flow calculations. The pudendal vein in the bovine can only be occluded surgically, however representative samples can be obtained by using a flexible catheter, inserted into the milk vein and pushed caudally until its tip, and thus the location of sampling, is close to the gland itself.

The Fick method is still widely used (Hanigan et al., 1991; Hanigan et al., 1992; Cant et al. 1993), though several of the necessary assumptions are often invalid over short time periods. Blood flow to any organ is usually variable over time (Mepham, 1982), and arterial concentration of most metabolites varies with time, influenced largely by stage of lactation and the cows feeding regime. These compromises are recognised, however the method does provide reasonable results if blood sampling is done often and it is assumed that the mean arterial concentration and metabolite secretion rate, over the time of blood sample collection are representative of steady-statc metabolism in the animal. The results provided are mean blood flow, and mean net arteriovenous uptake over the sampling time period, therefore this method is limited to measuring chronic responses to perturbations and hence is somewhat limited when attempting to identify acute control mechanisms associated with kinetics of mammary AA uptake.

Uptake and metabolism

Experimental work which has been performed with a goal of characterizing AA uptake by the lactating mammary gland, and AA metabolism within the gland 
can be subdivided into four categories:

1) the system has not been perturbed by AA infusion;

2) infusion of unlabelled AA;

3) infusion of radio-labelled $\mathrm{AA}$;

4) infusion of stable isotope labelled AA.

(a) No infusion

As early as 1966 , it was shown that mammary arteriovenous AA uptake from plasma by the lactating mammary gland was sufficient to provide the nitrogen in mammary-origin milk proteins of the goat (Mepham and Linzell, 1966). When quantities of individual AAs were considered, essential AA (EAA) uptake was approximately equal to that secreted in milk. Mammary uptake of non-essential AAs (NEAAs) was variable, with some AAs being extracted in quantities much greater than that secreted in milk. The net extraction rate, by the gland from blood plasma, averaged $36 \%$ for EAAs, the highest being Met at $77 \%$ (Mepham and Linzell, 1966). In contrast NEAAs extraction averaged only $24 \%$. The methods employed in this experiment allowed estimation of net AA balance across the gland and $\mathrm{AA}$ accumulation within the gland, however they could not differentiate total versus net uptake of AAs, or specific paths of AA metabolism within the gland. The work was a significant step forward, both in experimental methodology and in understanding of AA metabolism. Some of the theories regarding mammary AA metabolism brought to the forefront were that excess uptake of some EAAs might be transaminated within the gland to supply the requirements of those NEAAs which were not extracted in sufficient quantities to supply output in milk. Subsequently EAAs were divided into two groups:

1) group-I EAAs, including Met, Phe, Tyr, histidine (His) and tryptophan (Trp) which were taken up by the gland and transferred stoichiometrically to milk;

2) group-II EAAs, including threonine (Thr), Val, Leu, Ile, lysine (Lys) and arginine (Arg) which were extracted by the gland in greater quantities, than that secreted in milk.

The percentage extraction of group-I EAAs was generally higher than that of group-II EAAs (Mepham et al., 1992) which led to the hypothesis that group-1 EAAs, were most likely to limit the overall process of milk protein synthesis rate.

Estimates of mammary AA uptake of 4 cows producing from 12.6 to 22.9 litres of milk per day, showed that Met consistently had the highest extraction rate, however the AA balance (uptake/milk output) and mammary gland extraction ratio was different for individual AA (Bickerstaffe et al., 1974). A comprehensive experiment measured arteriovenous difference across the mammary gland of 21 lactating cows, blood sampled 4 times at 35 day intervals during the first half of lactation (Hanigan et al., 1991). Arteriovenous difference estimates of individual 
AAs, across the gland, were consistently higher when analysis was done on whole blood compared to analysis on blood plasma. This suggests that whole blood rather than plasma better represents the true AA precursor pool for milk protein synthesis. Plasma analysis has traditionally been used because laboratory analysis methods for estimating AA concentrations in whole blood are more involved. Whether AAs are transferred directly from red blood cells to lactating alveolar cclls, or indirectly through the plasma pool is inconclusive. A second analysis of the same data to determine kinetic parameters of uptake suggested that for many AAs, including all group-I EAAs, with the exception of Trp, net extraction by the mammary gland was correlated linearly with arterial concentration (Hanigan ef al., 1992). Arterial Met concentration was positively correlated with arteriovenous Met uptake by the gland, and concomitantly with milk protein yield (Hanigan et al., 1992). Extraction of a different group, including all group-I EAAs except Phe, were correlated with arteriovenous difference of Met, suggesting that it was the first limiting $\mathrm{AA}$ in this experiment. A kinetic equation was developed to describe AA uptake, relative to arterial concentration. The equation was a form of the normal Michaelis-Menten saturation type equation, with an extra exponential term (Hanigan et al., 1992). This exponential term causes the response in uptake to increased arterial AA concentration, to be of sigmoid shape, and thus more sensitive over the normal physiological range of arterial AA concentrations. The equation adequately describes net $\mathrm{AA}$ uptake however fails to recognize bidirectional fluxes between blood and the gland, and appears to have the underlying assumption that AA uptake by the gland is a "push" mechanism whereby AA uptake can be increased simply by increasing arterial concentrations of limiting AAs.

\section{(b) Unlabelled infusions}

Cant et al. (1993) attempted to ascertain the mechanism of milk protein depression associated when cows are fed diets containing added fat. Hydrolysed casein, but not fat, infused into the abomasum was associated with increased arterial AA concentrations and arteriovenous EAA differences across the mammary gland. Milk nitrogen content increased with casein infusion and decreased with fat infusion. Mammary blood flow, calculated using the Fick principle and Phe + Tyr output in milk, suggested that abomasal fat infusion was associated with reduced mammary blood flow. When both casein and fat were infused, mammary blood flow decreased and EAA extraction rate increased, thus the net quantity of EAAs removed by the gland was unchanged. This suggests that mammary blood flow was locally controlled by arterial concentrations of "energy yielding" substrates such as acetate, glucose and B-hydroxybutyrate. Therefore total milk yield increased, but AA uptake and protein yield remained constant, resulting in reduced milk protein per cent. 
Casein infused into the duodenum increased milk, milk fat and protein yields, as well as protein content of milk, yet blood flow was not affected (Guinard et al., 1994). Arterial AA concentrations, which were calculated from duodenal appearance of protein, increased as did extraction of all AAs, however the net increase in quantity of AA extracted was much greater for EAAs than NEAAs. Increased AA uptake was not transferred directly to milk protein. The concentration of all component milk proteins increased in equal proportion and the mammary blood flow to milk output ratio actually decreased resulting in reduced AA utilization efficiency, with increasing amounts of casein infused. Mammary AA uptake, milk output, and milk output per unit mammary uptake of both EAAs and NEAAs increased in a curvilinear fashion as duodenal flow of AAs increased, in a normal saturation kinetic fashion but the curve approached plateau much more quickly for NEAAs than EAAs. This experiment attempted to demonstrate the response of the mammary gland to a specific perturbation of arterial AA profile, in an effort to bring the arterial AA profile closer to that of casein.

Subsequently this data set broken down from EAAs and NEAAs groups to individual AAs (Guinard and Rulquin, 1994a). The calculated quantity of Phe added to arterial blood by casein infusion was completely extracted by mammary gland. The ratio of uptake to milk output increased for all EAAs as casein infusion rates increased, suggesting that increasing NEAA concentration may have reduced the obligatory requirement for EAAs. Group-I AAs were almost completely utilized for milk protein synthesis. AA balances across the gland, calculated from this data set, predicted large accumulation of AAs by the gland, which is highly unlikely over the long term. Positive mammary gland AA balances over extended periods, would suggest that the quantity of alveolar or constituent tissue in the gland increases constantly. This dilemma could have been caused by analysis of plasma as opposed to whole blood, or accuracy of the calculations used to predict AA uptake across the small intestine, and hence arterial AA concentration. This method does not accommodate calculation of net versus total AA uptake but the authors do suggest that mammary AA uptake may be regulated by intracellular processes.

Duodenal infusion of Lys, which is often considered to be one of the first limiting AAs for milk protein synthesis, failed to increase milk, fat or protein yield (Guinard and Rulquin, 1994b). However Lys infusion was associated with increased milk protein content and increased $\mathrm{N}$ utilization by the mammary gland. At the lower Lys infusion rates, Lys uptake by the gland balanced Lys output in milk, but at higher infusion rates Lys uptake exceeded output in milk, suggesting that it was no longer the limiting AA.

Data sets such as these are very useful in terms of net AA uptake and also total AA output in milk, however they are less useful to identify mechanisms that control AA uptake or metabolism. Metabolism within the gland is still generally trea- 
ted as a black box because these experimental methods are unable to elucidate specific pathways of AA metabolism, such as protein translation, AA oxidation or AA transamination. More insight can be gained from such data sets when they are combined in the form of a model, and then challenged with other data sets. These methods allow observation of overall responses in terms of milk output to an applied treatment, however estimation of the rate of intra-mammary AA metabolism, including transamination or oxidation requires the use of labelled AA.

\section{(c) Radio-labelled infusions}

The next important development, the use or radio-labelled amino acids, allowed estimation of direction and magnitude of many metabolic pathways such as bidirectional AA flux rates, AA oxidation, AA transamination and rate of AA translation into milk protein. Dually $\left[\mathrm{U}^{-14} \mathrm{C} ; 2,3-{ }^{3} \mathrm{H}\right]$ labelled Leu, Phe, Thr and Val, infused into isolated perfused goat mammary glands showed that $90,96,85$ and $93 \%$, respectively of these AAs in milk casein were derived directly from blood free AAs (Verbeke et al., 1972; Roets et al., 1979, 1983). This technique allowed estimation that $36 \%$ of Leu, $0 \%$ of Phe, $15 \%$ of Thr, $0.3 \%$ of Tyr, and $30 \%$ of Val taken up by the gland was oxidised to $\mathrm{CO}_{2}$. Ten per cent of Val and $8 \%$ of Leu found in mammary venous blood had been reversibly transaminated, i.e. converted to another $\mathrm{AA}$, and then back to the original AA, during a single pass through the gland. This demonstrated the presence of bidirectional AA uptake by the mammary gland (Roets et al., 1979, 1983). Seventy to eighty per cent of Leu molecules found in casein had been reversibly transaminated before incorporation into milk protein (Roets et al., 1983). In two separate experiments, there was large variation in the amount of conversion of Phe to Tyr suggesting that phenylalaninehydroxylase activity may be influenced, directly or indirectly, by the concentration of Phe and Tyr in blood. Infusion of radioactively labelled Val, Leu, His and Phe into isolated perfused guinea-pig mammary glands corroborated that amino acids in milk protein were derived from perfusate, Phe and His were transferred stoichiometrically into casein, and Val was oxidised to $\mathrm{CO}_{2}$ (Davis and Mepham, 1976).

An experiment using ${ }^{14} \mathrm{C}$-Leu infused into the artery supplying the mammary gland of a lactating goat (Oddy et al., 1988), was the first attempt to quantify bidirectional flux of AA uptake, and the magnitude of mammary gland constituent tissue protein turnover. Estimates of tissue protcin turnover allow calculation of total AA flux to and from the tissue protein pool, which could theoretically be used as a source of AAs for milk protein synthesis, for short time periods. The results suggested that mammary constituent tissue turnover is considerable, at approximately $30 \%$ per day, and therefore is a potential precursor pool for milk protein. 


\section{(d) Stable isotope infusions}

The most recent advance in the study of mammary AA uptake and metabolism involves infusion of AAs labelled with stable isotopes and analysis using massspectrometry techniques. The major advantage of this method over previous radioactive labelling methods is that problems of handling and disposal of radioactivity are overcome. A compromise is that isotope enrichment in products must be increased to allow accurate measurement, therefore quantities of infused label must be increased, and in some cases may actually perturb the system being studied. ${ }^{13} \mathrm{C}$-labelled Leu, Phe, and Met infused systemically into four lactating goats showed that plateau enrichment of casein occurred approximately $16 \mathrm{~h}$ after infusion was started (Bequette et al., 1994). This delay corroborated previous suggestions of the presence of at least one intermediate precursor pool between blood and milk protein. Casein isotope enrichment was eventually higher than the venous blood draining the gland, therefore the authors suggest that some other source of amino nitrogen, found in blood, such as plasma peptides, must also be a precursor for milk protein. However this is only one of several possible explanations. Enrichment levels are close enough to be within the range of experimental error, specifically venous blood enrichment does not appear to be significantly different from that of secreted casein however standard errors or probability values were not given. Furthermore, casein as opposed to all mammary-origin proteins, was analyzed for isotope enrichment, and blood analysis was done on plasma, instead of whole blood. Both of these experimental considerations could have affected the results. This technique, using systemic infusion, opposed to local infusion to the mammary gland, negated the ability to ascertain presence of bidirectional flux at the site of AA uptake or if labelled AA was transaminated to a different AA during passage through the mammary gland. Backwell et al. (1994) suggested that AAs in peptide form are absorbed by the mammary gland and subsequently translated to casein however whether the peptide is taken up by the cell intact or hydrolysed prior to uptake is still inconclusive. A mechanistic model (France et al., 1997), produced using the same data did not support peptide involvement in milk protein synthesis.

In separate experiments, the amino acids Phe, Thr, Ile, Leu, Val, and glutamate (Glu) have all been identified as potentially limiting milk protein synthesis (Cant and McBride, 1995b), demonstrating the disparity in research findings. This is not surprising when the wide variation in diet composition fed to these animals is considered. Comparison of AA flows to the duodenum versus calculated potential milk yield, showed that Met, Lys, His, Ile, and Leu were found to be limiting milk protein yield in $25,17,13,2$, and 2 experiments respectively, and efficiency of protein production, defined as milk protein yield divided by calculated maximum protein yield, ranged from 0.32 to 0.76 . This variability supports the need for a mechanistic dynamic mathematical model to combine previous quantitative infor- 
mation and allow prediction of the kinetics of process involved in milk protein synthesis and secretion, over a wide range of dicts.

Experiments such as these made a significant contribution to the base of knowledge and understanding of mammary AA metabolism, however they also cncompassed some important compromises. All results report incorporation of AAs into cascin, but failed to measure AA utilization for other proteins synthesized within the gland, and exported into milk, in particular $\alpha$-lactalbumin and $\beta$-lactoglobulin, which comprise $13.4 \%$ of protein found in bovine milk (Davies and Law, 1980). Secondly, much of the work was done using small ruminants, or rodents for several reasons. They were less expensive to acquire and maintain, much smaller quantities of expensive radioactive tracer were required, and disposal of the radioactive animal carcass after completion of the experiment was simpler, compared to similar experiments utilizing cows. These animal models have been used successfully to gain insight into milk protein synthesis, however species differences such as milk composition, range of diets, and normal arterial AA concentrations suggests that inferences can be made confidently to bovine milk protein synthesis in a qualitative sense. However, quantitatively, the magnitude of flux of all AAs, or specific individual AAs could be much different in the cow.

\section{EXTANT MATHEMATICAL MODELS}

A number of models have been written and tested and are now widely used in research, teaching and extension. Several have been written to describe whole animal metabolism of the lactating dairy cow (Baldwin et al., $1987 \mathrm{a}, \mathrm{b}, \mathrm{c}, 1995$; Danfær, 1990; O'Connor et al., 1993) and these usually have a component describing lactating mammary gland metabolism. Models have also been written to study comprehensive mammary metabolism (Waghorn and Baldwin, 1984; Hanigan and Baldwin, 1994) or specific components, such as Leu metabolism (France et al., 1995), or control of mammary blood flow (Cant and McBride, 1995a).

\section{(A) ORGAN MODELS}

The first dynamic mechanistic model of bovine mammary gland metabolism (Waghorn and Baldwin, 1984) was written specifically to balance carbon flow into and out of the mammary gland, with particular emphasis on the energetic costs of synthesizing the components of milk. The authors state that previous investigations of the chemical and biological processes in lactating mammary tissue were relatively comprehensive however a dynamic model integrating this information to evaluate its ability to describe milk synthesis and secretion was lacking. The 
model represents a $650 \mathrm{~kg}$ Holstein cow producing $15 \mathrm{~kg}$ of milk per day of composition $4.8 \%$ lactose, $3.5 \%$ fat, and $3.6 \%$ crude protein. Mammary blood flow is set at $500 \mathrm{ml}$ of whole blood per $\mathrm{ml}$ of milk produced and packed cell volume at $30 \%$, therefore the ratio of mammary plasma flow to milk produced was $350: 1$. The model described fluxes of radioactively labelled substrates to quantify the contribution of pyruvate as a source of energy for fatty acid synthesis. This required addition of kinetic equations to trace the path of each individual carbon from glucose, pyruvate and acetate. The relatively low level of milk production was selected because parameters included in the model were experimentally derived from low-producing or late lactation cows.

This model appears to meet the goals of the project, namely that estimates of carbon flow through the gland were adequate to support low levels of milk synthesis. Carbon flux rates and pool sizes were within physiological ranges. It does not however address the subtleties of amino acid uptake and protein synthesis, which were not part of the project. Nitrogen taken up by the gland balanced $\mathrm{N}$ outputs in all mammary origin proteins however allowance was not made for mammary tissue protein turnover, AA oxidation or AA transamination. The model showed clearly that estimates of EAA uptake from blood plasma in previous experiments, was not sufficient to meet the absolute EAA requirements for milk synthesis. In the case of several individual AAs, predicted uptake had to be doubled to balance input with output, corroborating earlier suggestions (Mepham, 1982) that erythrocytes might be contributing AAs to milk protein. The model was unstable when changes were made in arterial concentrations, due to the use of mass action (i.e. non-saturable) kinetic equations, which were found to be inadequate.

The mammary model of Waghorn was subsequently updated (Hanigan and Baldwin, 1994) such that most fluxes were converted to Michaelis-Menten saturation kinetics, and the description of AA uptake and metabolism was expanded. This model consists of 62 differential equations and 32 state variables and is mechanistic in the areas of energy substrate metabolism and fat synthesis. The model traces individual radioactively labelled carbons, analogous to infusion of labelled glucose or lactate, through intermediary metabolism via citrate, $\alpha$-ketoglutarate and malate to final products such as $\mathrm{CO}_{2}$ and labelled carbon in milk fatty acids. The areas of AA uptake, AA metabolism and protein synthesis are present but are represented in less mechanistic detail than that of metabolism of energy yielding substrates. Provision for tracing the fate of labelled AAs was not made in this model. Intracellular AA concentrations are assumed to be the same as that of extracellular, which conflicts with previous reports of concentrative uptake by AA transporters in most tissues (Christensen, 1990) including mammary tissue (Baumrucker, 1985). While intracellular and extracellular concentrations are assumed to be the same, the energetic costs of AA transport, in terms of ATP utilization, is identified in total requirements of the gland. The model also 
accounts for production of some NEAAs such as Ser, glycine (Gly), and proline (Pro) from glyceraldehyde-3-phosphate and Arg or ornithine (Orn).

In the model of Hanigan and Baldwin (1994) protein synthesis rate is controlled by a routine that continuously monitors intracellular concentration of EAAs and limits the protein synthesis rate based on the one AA, which is lowest at any point in time. In general all EAAs are grouped together into a single pool which go directly to a milk protein pool, with the excess being oxidised. Uptakes of EAAs are unidirectional Michaelis-Menten saturation type equations with an exponent applied to the substrate/affinity constant ratio which allows a sigmoid response in AA uptake with respect to the arterial concentration. However previous work with both AA transporters (Christensen, 1990) and lactating mammary glands suggest that AA transport is actually bidirectional. Therefore AA uptake in this model of the EAAs is strictly arterial concentration driven, which implies that increasing arterial concentration "pushes" increased quantities of all AAs into the cell.

This model (Hanigan and Baldwin, 1994) also provides a major step forward in our understanding of bovine mammary metabolism. It does provide useful information regarding which labelled metabolites are required, and the specific locations at which the label must be attached to obtain useful kinctic information from subsequent experiments. It also suggested that previous estimates of activity levels of several mitochondrial and cytosolic enzymes involved in oxidative metabolism were too low to support normal milk production, and therefore must be reassessed experimentally. The authors do correctly point out several areas where key data is missing, such as mammary AA uptake and milk protein translation. While much of this information is missing, we do have knowledge of many of the constraints involved in the process of milk protein synthesis, which could be incorporated into a model. This would produce different model outputs in terms of pool sizes and flux rates when the animal is at steady-state.

A model was written to study mechanisms controlling bovine mammary blood flow and the effects of perturbing these various mechanisms on nutrient uptake by the gland (Cant and McBride, 1995a). Nutrients taken up by the gland for milk synthesis were grouped into four groups: glucose, acetate, fatty acids, and amino acids. In this model, previous mammary balance data was used and intra mammary metabolism of these nutrients was not addressed. AA uptake by the gland is described by mass-action kinetics and all AAs are grouped together. AA uptake in excess of that incorporated into milk protein is oxidised. Thus uptake of AAs by the gland is unidirectional. The model predicted that increasing mammary blood flow, by increasing artcrial pressure, analogous to neural regulation, without altering arterial metabolite concentrations resulted in reduced uptake of all nutrients except acetate. However, when arterial metabolite concentrations were altered, intracellular adenylate charge changed, resulting in local control of blood flow by opening or closing pre-capillary sphincters, thus increasing or decreasing total 
mammary blood flow. When blood flow was manipulated by local control, nutrient uptake and milk synthesis rate did increase in response to increasing arterial concentrations. Under this method of control, relatively small changes in arterial concentration had large effects on quantity of nutrients taken up. These results also suggest that blood flow is controlled locally, primarily by the arterial concentration of energy yielding metabolites. Therefore milk protein yield and concentration would be maximised at some optimum level of energy yielding metabolite to AA concentration ratio.

The model of France et al. (1995) was written to resolve mammary uptake and metabolism of arterial Leu under steady state conditions. Three mid-lactation cows, with milk yields ranging from 22.9 to $25.6 \mathrm{~kg} \mathrm{~d}^{-1}$, were fed a diet containing either high or low protein content. Data were derived from an experiment where ${ }^{13} \mathrm{C}$ labelled Leu was infused systemically into the jugular vein for $16 \mathrm{~h}$ and the pattern of Leu enrichment in both blood and milk protein was measured under steadystate conditions. Inputs into the model are mammary blood flow, arterial and venous Leu concentration, enrichment of Leu in milk protein-bound and milk free pools. The model predicts bidirectional Leu uptake by the gland, bidirectional flux from intracellular free pool to constitutive tissue protein, bidirectional flux from intraccllular free pool to milk protein, and intracellular Leu oxidation. Infusion was systemic, therefore arterial enrichment was estimated from enrichment of free Leu in milk, which is presumed to be the same as that of the true precursor pool. Intracellular Leu oxidation, transamination or translation to whey proteins was not accounted for in this model. Solving the model showed that approximately $67 \%$ of the Leu presented to the mammary gland was extracted, and that $65 \%$ of that extracted went directly to secreted milk protein. This model, with some minor alterations to the experimental methods used in vivo can theoretically be used to rank each individual AA in terms of potential to limit milk protein synthesis, and thus predict the ideal AA pattern to provide to the bovine mammary gland. A subsequent model was used to evaluate the contribution of arterial AA, in peptide form to milk protein synthesis in the ruminant mammary gland using a dual-labelled tracer technique (France et al., 1997).

\section{(B) WHOLE ANIMAL MODELS}

The dairy nutrition group at Cornell University published a model (O'Connor et al., 1989), which combined the National Research Council recommendations for dairy cow feeding in a linear programming ration formulation program. Subsequently the model was updated (Fox et al., 1992; Russell et al., 1992; Sniffen et al., 1992; O'Connor et al., 1993) to integrate information in the area of rumen degradable and rumen undegradable protein requirements for lactating dairy cows 
and was designed to formulate least cost rations for a given level of production. The empirical nature of the model does predispose it to some significant compromises. For example, the empirical equations suggest that fibrolytic microbial growth ceases when rumen fluid $\mathrm{pH}$ drops below 5.7, and even when the fibrolytic bacteria disappear, the model suggests that fibre digestion continues (Dijkstra et al., 1998). Of particular importance when considering milk composition and milk protein synthesis is the compromise that the CNCPS model fails to accommodate the increased efficiency of rumen microbial growth when the supply of amino acids and peptides, as opposed to ammonia, is increased. This model is now widely used for agricultural extension applications such as dairy ration formulation and operates on the traditional approach of predicting nutrient requirements for a set input level of milk production. Its application to research or defining mechanisms which limit milk, or milk component synthesis is limited because milk yield and composition are required as inputs into the model.

The model of Danfer (1990) is a mechanistic, deterministic, dynamic whole animal model of a lactating dairy cow. The model has 9 tissuc compartments representing rumen, intestinal lumen, intestinal wall, liver, peripheral blood and extracellular fluid, mammary gland, muscle tissue, adipose tissue, and other tissues. The units are moles of carbon and nitrogen and the integration interval is one day, therefore flux rates are in units of moles of $\mathrm{C}$ and $\mathrm{N}$ per day. Carbon pools represent carbohydrates, lipids and other nitrogen-frec carbon substances, while nitrogen pools represent protein, peptides, amino acid, ammonia/ammonium, and urea. Kinctic equations use Michaelis-Menten saturation or first-order mass action kinetics. Input variables required by the model include chemical composition of the feed, cow live weight and stage of lactation. The model predicts feed dry matter intake, milk yield, milk composition, live weight gain, tissue energy balance, milk energy yicld, total energy intake, metabolic energy losses, and net energy intake. This model is composed of 77 state variables, and 1500 equations, 340 of which are differential equations.

The structure of this model implies that milk protein synthesis rate is equal to amino acid uptake rate, by the gland, and milk protein secretion rate is equal to that of protein synthesis, both which are known to be oversimplifications, from studies of mammary metabolism in other ruminants (Oddy et al., 1988). The model was tested using data from a previous experiment using different diets as treatmonts. In general, the model performed well except that milk yield was underestimated and live weight gain was overestimated.

Danfær wrote a good comprehensive critique of the strengths and weaknesses of his model, and states clearly that regulation of mammary gland capacity for milk synthesis requires mechanistic description. Two critical issues that are known to be oversimplificd in this model are that rate of milk synthesis is regulated only by substrate availability, and synthetic capacity does not change with progressing lactation. 
The fact that the author could write such a clear and comprehensive critical summary demonstrates the value of the process of mechanistic modelling, namely that the scientist can identify key areas of knowledge and understanding which are lacking.

The most comprehensive mechanistic model of metabolism in the lactating dairy cow was originally assembled by Baldwin et al. (1987a, 1995). The purpose of this modelling project was to determine if data and concepts produced from tissue culture and cell culture experiments could be utilized to produce a dynamic rescarch model amenable to evaluation of mechanisms and hypotheses about partitioning of nutrients in the lactating cow. Experimental work involving effects of recombinant bovine somatotropin on lactating cows suggested that it was an effective partitioning agent, allowing the cow to preferentially channel nutrients to milk, and away from body tissue synthesis (Bauman and McCutcheon, 1986). The mechanism of this partitioning effect was unknown, yet of considerable interest. Thus the model is heavily orientated toward energy balance within the whole animal in an effort to explain this partitioning effect.

Inputs required by the model are the supply of propionic acid, glucosc, acetic acid, fatty acids, butyric acid and AA in moles per day. The model describes total body pools of adenosine diphosphate (ADP), adenosine triphosphate (ATP), acetic acid, butyric acid, fatty acids, glucose, glycerol, lactic acid, lactose, propionic acid, triglyceride in milk and triglyceride in storage, and predicts oxygen consumption and carbon dioxide production.

Total body free amino acid, body protein and milk protein pools are also recognised. All AAs are combined into a single pool. Fluxes describing AA absorption from the gastrointestinal tract, used for milk protein and used for gluconeogenesis arc unidirectional. Fluxes of AAs from the body free pool to body protein and body visceral protein pools are bidirectional. Fluxes of AAs from viscera and adipose tissue to the free AA pool are described using mass action kinetics, because of lack of information to parameterize more complex cquations. The remaining cquations calculating metabolite fluxes, including AAs, are either one- or twosubstrate Michaelis-Menten saturation kinetic equations. Provision is made to change the affinity for $\triangle A$ s for synthesis of body protein, visceral protein, and gluconeogenesis in response to altered hormonal levels.

The model successfully predicted the apparent costs of milk synthesis, in terms of energy yielding substrates. It predicted that more than half of the cost of milk synthesis is directly attributable to biosynthetic costs. The remaining costs were distributed between heart work and respiration, ion transport as well as the cost to resynthesise protein and triglyccride in milk from mobilized body stores. When mammary capacity was increased, milk yield increased but milk protein content did not change, as had been observed in the rbST experiments. The authors make an important observation that most responses of the model to specific metabolic perturbations could well have been predicted a priori, however the magnitude of 
complexity of the responses involving several metabolites, could not have been predicted or comprehended. The number and magnitude of interactions between metabolites is too complex to comprehend, even in a qualitative sense without a model. Subsequently this model was expanded by inclusion of a rumen digestion model and uscd to describe whole cow metabolism over an entire lactation (Baldwin et al., 1987b, c, 1995).

While this model compiles a tremendous quantity of information in the area of biochemistry and metabolism of the lactating cow, it was not designed to test hypotheses relative to specific mechanisms controlling milk composition, or identify mechanisms which limit the rate of milk protein synthesis. Amino acids are pooled together in a single pool and neither AA uptake by the mammary gland, or intracellular protein synthesis are represented mechanistically in that this model does not describe AA efflux from the gland to blood or extent of intracellular milk protein degradation.

\section{CONCEPTUAL FRAMEWORK FOR FUTURE MODELLING}

Previous research appears to mirror the market trends for dairy products. Initially research emphasis was focussed on increasing total milk volume which stimulated interest in mammary uptake and utilization of glucose and acetate for lactose synthesis. Subsequently interest in mammary fatty acid uptake and synthesis, for milk fat production, took priority. More recently mammary AA metabolism, and interest in milk protein synthesis, has been primarily focussed on establishing that amino acids in blood were precursors for milk protein and that the quantity of EAAs taken up by the mammary gland balanced the quantity secreted in milk. Therefore the volume of published literature in the area of metabolite uptake and metabolism within the ruminant mammary gland appears large, however a small proportion of this total focusses on mammary AA uptake and protein metabolism.

Interest in sustainable agriculture, and in some European countries the issue of livestock manure disposal, has stimulated interest in minimising nitrogen excretion. Analogous to this is interest in maximising efficiency of nutrient utilization, or optimising milk protein synthesis efficiency. The difference between maximising efficiency vs maximising production is a subtle but important differentiation. A robust mechanistic model of milk protein synthesis will be very useful in testing various feeding and management scenarios, and to design appropriate experiments in this area.

Mathematical models of mammary protein synthesis will have much greater utility in the future if they represent:

1) total AA uptake describing uptake of each individual AA, recognising the specific AA transporter which accomplishes this uptake; 
2) bidirectional fluxes of AAs, both at the level of mammary uptake, and also with mammary constituent tissue and milk protein synthesis;

3) $\mathrm{AA}$ requirements for all mammary-origin proteins, including $\alpha$-lactalbumin and B-lactoglobulin;

4) the documented biology and metabolism of mammary tissue in a mechanistic form.

The process of modelling this complex process may also be simplified substantially if biological "constraints" are judiciously included. For example the intracellular machinery that translates milk protein cannot proceed based on intracellular concentration of AA "mixtures". The AA profile of all mammary origin proteins is

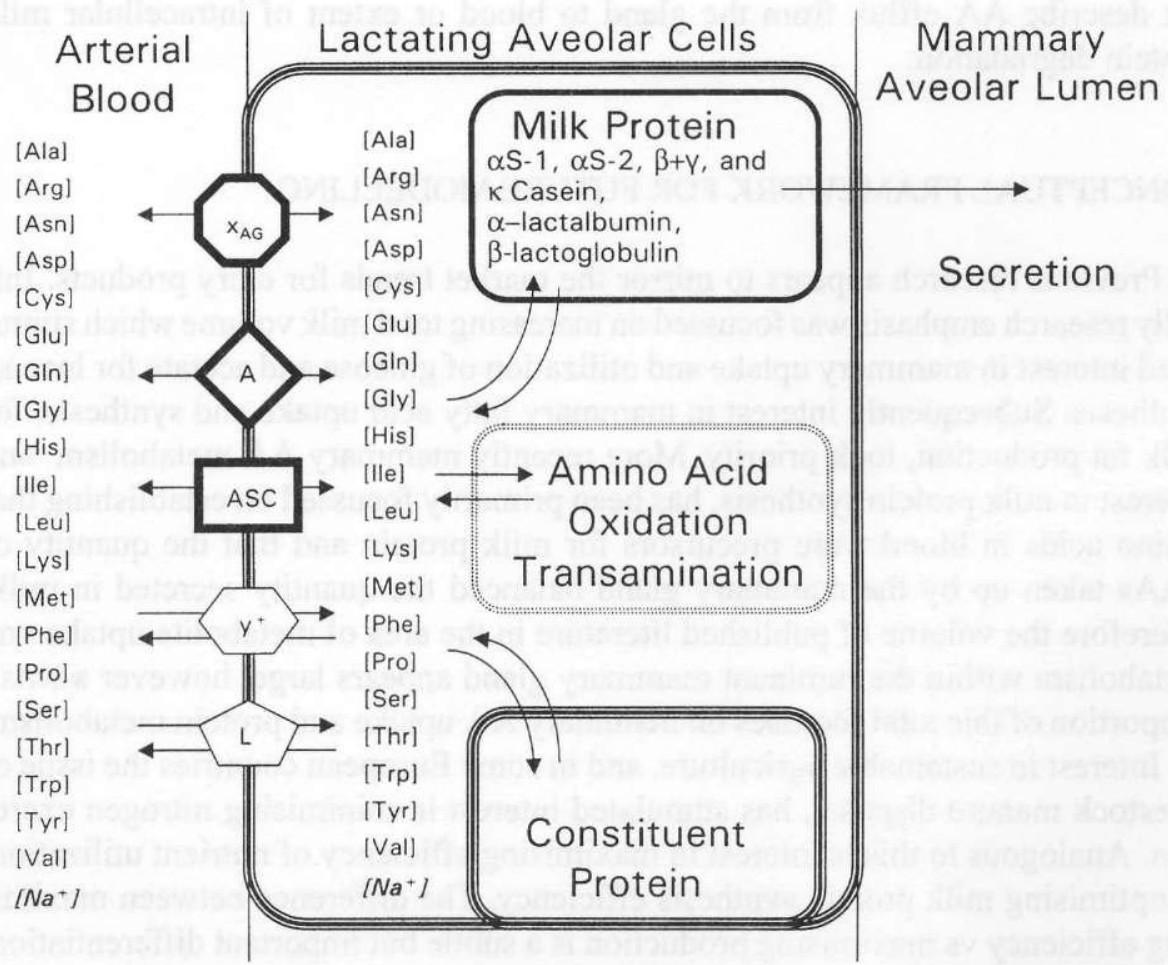

Figure 1. A conceptual framework for a mechanistic model of amino acid uptake and metabolism, and protein synthesis within the lactating bovine mammary gland. Square brackets denote the concentration of individual amino acids in arterial blood and in the cytosol of the lactating alveolar cell respectively. Amino acids are transported into the cell by membrane bound sodium-dependent $\left(\mathrm{X}_{\mathrm{AG}}\right.$, $\mathrm{A}, \mathrm{ASC})$ or non sodium-dependent $\left(\mathrm{y}^{+}, \mathrm{L}\right)$ transporters. Intracellular amino acids can be used to synthesize milk protein or cellular constituent protein, or can be oxidized or transaminated to another amino acid. Each of these metabolism processes is bi-directional. Milk protein is secreted into the alveolar lumen after an appropriate time delay to allow for post-translational modifications 
fixed, and therefore translation can only proceed at the rate at which the first limiting AA, among all 20 , is supplied.

Figure 1 demonstrates a proposed model of AA uptake and metabolism by the lactating bovine mammary gland. The model will describe uptake of individual AAs from arterial blood via transporters which reside on the basolateral membrane of the lactating alveolar cell. Transporters $\mathrm{X}_{\mathrm{AG}}$, A, and ASC are drawn with a heavy line to indicate that they are sodium-dependent, therefore the rate at which AAs are transported is dependent on the net sodium gradient across the membranc. The single, doublc-headed arrow indicates that they are bi-directional transporters however can only transport in one direction at any single point in time, depending on the orientation of the sodium gradient. The remaining $y^{\prime}$ and $L$ transporters which have also been identified in mammary tissue (Baumrucker, 1985), are non sodium-dependent and are thus drawn with light lines. These transporters operate by exporting an amino acid while simultaneously importing another. Therefore the rate of AA transport via these transporters is dependent on the relative concentration of individual AAs, shown in square brackets, on either side of the membrane. The figure shows that intracellular AAs are then available for each of several metabolic processes including synthesis of milk proteins and constituent tissue proteins which make up the cell and its contents. A proportion of both milk protein and constituent protein are hydrolysed intracellularly and the resulting amino acids recycled for subsequent use. Intracellular AAs are also available for transamination reactions to other AAs or to be oxidised in the tricarboxylic acid cycle. Milk proteins would be secreted to the alveolar lumen after an appropriate time delay to accommodate post-translational processes such as removal of the signal peptide, glycosylation, and phosphorylation. All transactions including AA transport, protein synthesis and degradation, and AA oxidation and transamination would be described mathematically using scveral forms of saturable Michaelis-Menten kinetic equations (France et al., 1998). We suggest that this is an appropriate representation of true mammary biology and that appropriate estimates for most of the required parameters are available in the literature. We propose devclopment of this mathematical model of mammary AA uptake and metabolism.

\section{REFERENCES}

Akers R.M., Bauman D.E., Capuco A.V., Goodman G.T., Tucker H.A., 1981. Prolactin regulation of milk secretion and biochemical differentiation of mammary epithelial cells in peripariurient cows. Endocrinology 109, 23-30

Backwell F.R.C., Bequette B.J., Wilson D., Calder A.G., Metcalf J.A., Wray-Cahen D., MacRae J.C., Beever D.E., Lobley G.E., 1994. Utilization of dipeptides by the caprine mammary-gland for milk protein-synthesis. Amer. J. Physiol. 267 Pt2, R1-R 6 
Baldwin R.L., Milligan L.P., 1966. Enzymatic changes associated with the initiation and maintenance of lactation in the rat. J. Biol. Chem. 241, 2058-2066

Baldwin R.L., France J., Gill M., 1987a. Metabolism of the lactating cow. I. Animal elements ol a mechanistic model. J. Dairy Res. 54, 77-105

Baldwin R.L., Thornley J.H. M., Beever D.E., 1987b. Metabolisın of the lactating cow. II. Digestive clements of a mechanistic model. J. Dairy Res. 54, 107-131

Baldwin R.L., France J., Beever D.E., Gill M., Thornley J.H.M. $1987 \mathrm{c}$. Metabolism of the lactating cow. III. Properties of mechanistic models suitable for evaluation of energetic relationships and factors involved in the partition of nutrients. J. Dairy Res. 54, 133-145

Baldwin R.L., 1995. Lactation. In: R.L. Baldwin (Editor). Modeling ruminant digestion and metabolism. Chapman and Hall, London (England), pp. 469-518

Bauman D.E., McCutcheon S.N., 1986. The effects of growth hormone and prolactin on metabolismin. In: L.P. Milligan, W.L. Grovum, A. Dobson (Editors). Control of digestion and metabolism in ruminants, pp. 436-455

Baumrucker C.R., 1985. Amino acid transport systems in bovine mammary tissue. J. Dairy Sci. 68, 2436-2451

Baumrucker C.R., Pocius P.A., 1978. $\gamma$-Glutamyl transpeptidase in lactating mammary secretory tissue of cow and rat. J. Dairy Sci. 61, 309-314

Bequette B.J., Backwell, F. R. C., Dhanoa, M. S., Walker, A., Calder, A. G., Wray-Cahen, D., Metcalf, J. A., Sutton J.D., Beever D.E., Lobley G.E., Macrae J.C., 1994. Kinetics of blood-free and milk casein-amino acid labeling in the dairy goat at 2 stages of lactation. Brit. J. Nutr. 72, 211220

Bickerstaffe R., Annison E.F., Linzell J.L.., 1973. The metabolism of glucose, acetate, lipids, and amino acids in lactating cows. J. Agric. Sci., Camb. 82, 71-85

Cant J.P., DePeeters E.J., Baldwin R.L., 1993. Mammary uptake of energy metabolites in dairy cows fed fat and its relationship to milk protein depression. J. Dairy Sci. 76, 2254-2265

Cant J.P., McBride B.W., 1995a. Mathematical analysis of the relationship between blood flow and uptake in the mammary glands of a lactating cow. J. Dairy Res. 62, 405-422

Cant J.P., McBride B.W., 1995b. Post-absorptive use of nutrients to optimize milk protein synthesis. In: M. Ivan (Editor). Animal science research and development: moving toward a new century. Agriculture and Agri-Food Canada, Ottawa, pp. 225

Christensen H. N., 1990. Role of amino acid transport and countertransport in nutrition and metabolism. Physiol. Rev. 70, 43-77

Christensen H.N., 1989. Distinguishing amino acid transport systems of a given cell or tissue. Methods in Enzymology 173, 576-616

Danfar A., 1990. A dynamic model of nutrient digestion and metabolism in lactating dairy cows. Ph. D. Thesis. Report from the National Institute of Animal Science, Denmark.

Davies D.T., Law A.J.R., 1980. The content and composition of protein in creamery milks in southwest Scotland. J. Dairy Res. 47, 83-90

Davis S.R., Mepham T.B., 1976. Metabolism of L- $\left[\mathrm{U}-{ }^{14} \mathrm{C}\right]$ Valinc, L-[U-1 $\left.{ }^{14} \mathrm{C}\right]$ Leucine, L-[U- $\left.{ }^{14} \mathrm{C}\right]$ Histidine and $\mathrm{L}-\left[\mathrm{U}-{ }^{4} \mathrm{C}\right]$ Phenylalanine by the isolated perfused lactating Guinea-pig mammary gland. Biochem J. 156,553-560

Dijkstra J., France J., Davies D. R., 1998. An evaluation of different mathematical approaches to predicting microbial protein supply in ruminants. J. Dairy Sci. 81 (in press)

Eisenstein R.S., Rosen J.M., 1988. Both cell substratum regulation and hormonal regulation of milk protein gene expression are exerted primarily at the posttranscriptional level. Mol. Cell. Biol. 8 , 3183-3190 
Foster R.C., 1977. Changes in mouse mammary epithelial cell size during mammary gland development. Cell Differentiation 6, 1-8

Fox D.G., Sniffen C.J., O'Connor J.D., Russell J.B., Van Socst P.J., 1992. A net carbohydrate and protein system for evaluating cattle diets: III. Cattle requirments and diet adequacy. J. Anim. Sci. $70,3578-3596$

France J., Bequette B.J., Lobley G.E., Metcalf J.A., Wray-Cahen D., Dhanoa M.S., Backwell F.R.C.Hanigan M.D., MacRac J.C., Beever D.E., 1995. An isotope dilution model for partitioning leucine uptake by the bovine mammary gland. J. theor. Biol. 172, 369-377

France J., Hanigan M.D., Bequette B.J., Metcalf J.A., Beever D.F., Lobley G.F., MacRae J. C., Backwell F.R.C., 1997. A model for quantifying the contribution of extracellularly-derived peptides to milk protein synthesis in the ruminant mammary gland. J. theor. Biol. 185, 379-388

France J., Dijkstra J., Dhanoa M.S., Baldwin R.L., 1998. Biomathematical applications in ruminant nutrition. J. Franklin Inst. 335B, 241-258

Gandolfi S.A., Maier J.A.M., Petronini P.G., Wheeler K.P., Borghetti A.F., 1987. Multicomponent analysis of amino acid 1ransport System $\mathrm{L}$ in normal and virus-transformed fibroblasts. Biochim. Biophys. Acta 904, 29-35

Gazzola G.C., Dall'Asta V., Guidotti G.G., 1981. Adaptive regulation of amino acid transport in cultured human fibroblasts. Biol. Chem. 256, 3191-3198

Gorewit R.C., Aromando M.C., Bristol D.G., 1989. Measuring bovine mammary gland blood flow using a transit time ultrasonic flow probe. J. Dairy Sci. 72, 1918-1928

Guidotti G.G., Borghetti A.F., Gazzola G.C., 1978. The regulation of amino acid transport in animal cells. Biochim. Biophys. Acta 515, 329-366

Guinard J., Rulquin H., Verite R., 1994. Effect of graded levels of duodenal infusions of casein on mammary uptake in lactating cows. 1. Major nutrients. J. Dairy Sci. 77, 2221-2231

Guinard J., Rulquin H., 1994a. Effect of graded levels of duodenal infusions of casein on mammary uptake in lactating cows. 2. Individual amino acids. J. Dairy Sci. 77, 3304-3315

Guinard J., Rulquin H., 1994b. Effects of graded amounts of duodenal infusions of lysine on the mammary uptake of major milk precursors in dairy-cows. J. Dairy Sci. 77, 3565-3576

Guinard J., Rulquin H., 1995. Effects of graded amounts of duodenal infusions of methionine on the mammary uptake of major milk precursors in dairy cows. J. Dairy Sci. 78, 2196-2207

Guyette W.A., Matusik R.J., Rosen R.J., 1979. Prolactin-mediated transcriptional and post-transcriptional control of casein gene expression. Cell 17, 1013-1023

Guyton B.C., Jones C.F., Coleman T.G.. 1973. Chapter 2. Measurement of cardiac output by the direct fick method. In: Circulatory Physiology: Cardiac output and its regulation, 2nd Edition. W. B. Saunders, Philadelphia PA, pp. 21-39

Hanigan M.D., Calvert C.C., DePeeters E.J., Reis B.L., Baldwin R.L., 1991. Whole blood and plasma amino acid uptakes by lactating bovine mammary glands. 1. Dairy Sci, 74, 2484-2490

Hanigan . M.D., Calvert C.C., DePeeters E.J., Reis B.L., Baldwin R.L., 1992. Kinetics of amino acid extraction by lactating mammary glands in control and sometribove-treated Holstein cows. J. Dairy Sci. 75, 161-173

Hanigan M.D., Baldwin R.L., 1994. A mechanistic model of mammary gland metabolism in the lactating cow. Agric. Syst. 45, 369-419

Huynh H.T., Robitaille G., Turner J. D., 1991. Establishment of bovine mammary epithelial cells (MAC-T): An in vitro model for bovine lactation. Exp. Cell Res. 197, 191-199

Jenness R., 1974. The composition of milk. In: B.L. Larson (Editor). Lactation: a comprehensive treatise III, Nutrition and biochemistry of milk/maintenance. Academic Press, New York, NY, pp. 3-107 
Linzell J.L., 1974. Mammary blood flow and methods of identifying and measuring precursors of milk. In: B.L. Larson (Editor). Lactation: a comprehensive treatise I, The mammary gland, development and maintenance. Academic Press, New York, NY, pp. 143-226

Linzell J.L., Mepham T.B., 1974. Effects of intramammary arterial infusion of essential amino acids in the lactating goat. J. Dairy Res. 41, 101

Mann G.F., Rudolphy-Bravo I., Yudilevich D.L., 1980. Kinetics of L-phenylalanine transport into the epithelium of the perfused cat submandibular gland. J. Physiol. (London) 307, 85P

Mepham, T.B., 1982. Amino acid utilization by the lactating mammary gland. J. Dairy Sci. 65, 287298

Mepham T.B., Linzell J.L., 1966. A quantitative assessment of the contribution of individual plasma amino acids to the synthesis of milk proteins by the goat mammary gland. Biochem. J. 101, 76-83

Miller L.P., Pardridge W.M., Braun L.D., Oldendorf W.H., 1985. Kinetic constants for blood-brain barrier amino acid transport in conscious rats. J. Neurochem. 45, 1427-1432

O'Connor J.D., Sniffen C.J., Fox D.G., Milligan R.A., 1989. Least cost dairy ration formulation model based on the degradable protein system. J. Dairy Sci. 72, 2733-2745

O'Connor J.D., Sniffen C.J., Fox D.G., Chalupa W., 1993. A net carbohydrate and protein system for evaluating cattle dicts: IV. Predicting amino acid adequacy. J. Anim. Sci. 71, 1298-1311

Oddy V. H., Lindsay D., Fleet I., 1988. Protein synthesis and degradation in the mammary gland of lactating goats. J. Dairy Res. 55, 143-154

Old I.G., Phillips E.V., Stockley P.G., Saint Girons I., 1991. Regulation of methionine biosynthesis in the enterobacteriaceae. Prog. Biophys. Mol. Biol. 56, 145-185

Pocius P.A., Baumrucker C.R., 1980. Amino acid uptake by bovine mammary slices. J. Dairy Sci. $63,746-749$

Razooki Hasan H., White D.A.. Mayer R.J., 1982. Extensive destruction of newly synthesized casein in mammary explants in organ culture. Biochem. J. 202, 133-138

Rocts E., Massart-Leën A., Verbeke R., Peeters G., 1979. Metabolism of $\left[\mathrm{U}-{ }^{-14} \mathrm{C} ; 2,3-{ }^{3} \mathrm{H}\right]-\mathrm{L}$-valine by the isolated perfused udder. J. Dairy Res. 46, 47-57

Roets E., Massart-Leën A., Peeters G., Verbeke R., 1983. Metabolism of leucine by the isolated perfused udder. J. Dairy Res. 50, 413-424

Rosen J. M., Supowit S.C., Guptak P., Yu L., Hobbs A. H., 1981. Regulation of casein gene expression in hormone-dependent mammary cancer. In: M.C. Pike, P.K. Siiteri, C.W. Welsch (Editors). Banbury report 8, Hormones and breast cancer. Cold Spring Laboratory. US, pp. 397-424

Russell J.B., O'Connor J.D., Fox D.G., Van Soest P.J., Sniffen C.J., 1992. A net carbohydrate and protein system for evaluating cattle diets: I. Ruminal fermentation. J. Anim. Sci. 70, 3551-3561

Scgel G.B., Simon W., Lichtman M.A., 1984. Multicomponent analysis of amino acid transport in human lymphocytes. J. Clin. Invest. 74, 17-24

Segel G.B., Woodlock T.J., Lichtman M.A., 1988. Trans-stimulation of L-system amino acid in normal and chronic leukemic human lymphocytes: Phorbol ester restores function in CLL. J. Cell Physiol. 134, 503-508

Shotwell M.A., Mattes P.M., Jayme D.W., Oxender D.L., 1982. Regulation of amino acid transport system $\mathrm{L}$ in chinese hamster ovary cells. Biol. Chem. 257, 2974-2980

Sniffen C.J., O'Connor J.D., Van Soest P.J., Fox D.G., Russell J.B., 1992. A net carbohydrate and protein system for evaluating cattle diets: II. Carbohydrate and protein availability. J. Anim. Sci. $70,3562-3577$

Streuli C.H., Bailey N., Bissell M.J, 1991. Control of mammary epithelial differentiaion: Basement membrane induces tissue-specific gene expression in the absence of cell-cell interaction and morphological polarity. J. Cell Biol. 115, 1383-1395 
Turner C.W., 1952. The mammary gland I. The anatomy of the udder of cattle and domestic animals. Lucas Brothers Publishers, Columbia, MO

Turner M.D., Rennison M.E., Handel S.E., Wilde C.J., Burgoyne, R.D., 1992. Proteins are secreted by both constitutive and regulated secretory pathways in lactating mouse mammary epithelial cells. J. Cell. Biol. 117, 269-278

Verbeke R., Rnets E., Massart-Leën A.M., Peeters G., 1972. Metabolism of [U-14C]-L-threonine and $\left[\mathrm{U}-{ }^{14} \mathrm{C}\right]-\mathrm{L}-$-phenylalanine by the isolated perfused udder. J. Dairy Res. 39, 239-250

Waghorn G.C., Baldwin R.L., 1984. Model of metabolite flux within mammary gland of the lactating cow. J. Dairy Sci. 67, 531-544

\section{STRESZCZENIE}

\section{Studia nad mechanistycznym modelem wchlaniania i przemian aminokwasów w gruczole mle- kowym krów}

W opracowaniu podano przegląd dostępnych $w$ literaturze informacji o pracach nad dynamiczno-mechanistycznym modelem przyswajania aminokwasów i ich wewnątrkomórkowym metabolizmem $z$ uwzględnieniem syntezy białka mleka i tkanek gruczołu mlekowego krów w okresie laktacji. Realistyczny model biologiczny, aby mógł być traktowany jako mechanistyczny, musi brać pod uwagę każdy $\mathrm{z}$ aminokwasów, wchłanianie $\mathrm{z}$ pomocą transporterów określone metodami in vitro oraz in vivo musi być opisane dwukierunkowo, a także musi uwzględniać zapotrzebowanie do wytwarzania w gruczole mlekowym wszystkich biakek z włączeniem $\alpha$-laktoalbumin i $\beta$-globulin. Koncepcyjne opracowanie szkieletu takiego modclu jcst zaawansowane. 